\title{
Calcium ionophore pre-treatment induces type-1 polarized DCs with enhanced T cell stimulatory function and IL-12 production
}

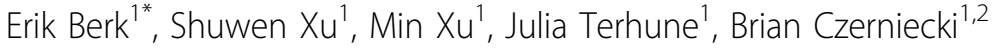 \\ From Society for Immunotherapy of Cancer 28th Annual Meeting \\ National Harbor, MD, USA. 8-10 November 2013
}

The effective treatment of cancer by immunotherapy requires the induction of high numbers of tumor-specific type-1 polarized T cells. Since DCs are the key antigenpresenting cells capable of activating and polarizing $\mathrm{T}$ cells, the generation of type-1 polarized DCs for DCbased anti-cancer therapies is desired. We have previously shown that DCs matured with calcium ionophore (CI) alone results in the generation of type- 2 polarized DCs, which lack IL-12 production. However, we now show that pre-treatment of monocyte-derived DCs with CI followed by the maturation with the inflammatory cytokine IFN $\gamma$ and the TLR agonists LPS (TLR2) and R848 (TLR7/8), results in an enhanced IL-12 production by the DCs compared to DCs matured without CI pre-treatment. The effect of CI on IL-12 production appears to be dependent on the kinetics of CI pre-treatment as well as on the maturation factors used following $\mathrm{CI}$ addition. The CI-matured DCs show a more mature phenotype (based on CD83 and CCR7 expression), express higher levels of the co-stimulatory molecule CD70, and have reduced expression of the inhibitory molecule PD-L1 compared to DCs matured without CI-pre-treatment. When loaded with antigen these CI-matured DCs strongly induce T cell proliferation and the expression of the cytolytic proteins granzyme B and perforin by CD8+ T cells in a mixed leukocyte reaction. The ability of $\mathrm{CI}$ to induce type-1 polarization with enhanced IL-12 secretion and T cell stimulatory function allows for the development of type-1 polarized DC-based anti-cancer vaccines.

\section{Authors' details}

'Department of Surgery and the Harrison Surgical Research Center, University of Pennsylvania, Philadelphia, PA, USA. ${ }^{2}$ Rena Rowan Breast Cancer Center, University of Pennsylvania, Philadelphia, PA, USA.

Published: 7 November 2013

doi:10.1186/2051-1426-1-S1-P199

Cite this article as: Berk et al:: Calcium ionophore pre-treatment induces type-1 polarized DCs with enhanced T cell stimulatory function and IL-12 production. Journal for ImmunoTherapy of Cancer 2013 1(Suppl 1):P199.
Submit your next manuscript to BioMed Central and take full advantage of:

- Convenient online submission

- Thorough peer review

- No space constraints or color figure charges

- Immediate publication on acceptance

- Inclusion in PubMed, CAS, Scopus and Google Scholar

- Research which is freely available for redistribution
C Biomed Central 